Journal of Indonesian Economy and Business

Volume 33, Number 2, 2018, 99 - 111

\title{
ANTECEDENTS AND CONSEQUENCES OF CARBON EMISSIONS' DISCLOSURE: CASE STUDY OF OIL, GAS AND COAL COMPANIES IN NON-ANNEX 1 MEMBER COUNTRIES
}

\author{
Dody Hapsoro \\ Accounting Department, STIE YKPN Yogyakarta, Indonesia \\ (dodyhapsoro@gmail.com) \\ Ambarwati \\ Accounting Department, STIE YKPN Yogyakarta, Indonesia \\ (ambarwattii@gmail.com)
}

\begin{abstract}
The purpose of this study is to determine the characteristics of companies that voluntarily disclose carbon emissions and to examine the economic consequences of the carbon emissions' disclosure. Companies used in the sample are oil, gas and coal companies in non-Annex 1 member countries registered in the Osiris database. The observation period was from the commencement of the Kyoto Protocol's second commitment to date, or from 2013 to 2016. Measuring the carbon emissions' disclosure is achieved by using a checklist developed from an information request sheet from the CDP (Carbon Disclosure Project). An assessment of the extent of the disclosure is made using the content analysis method. Company characteristics are proxied with leverage, profitability and firm age, while the economic consequences are proxied by using bid-ask spreads, the trading volume and share price volatility. The data analysis method used in this research is the Partial Least Square (PLS) method using the WarpPLS 4.0 application. Test results show that leverage, profitability and firm age have a positive effect on the carbon emissions' disclosure. Furthermore, the test results show that carbon emissions' disclosures have a positive effect on the trading volume and a negative effect on the bidask spreads and share price volatility. The above findings imply that firms with higher leverage, higher profitability and are older are more willing to reveal their carbon emissions' disclosures. The more information that is contained in a carbon emissions' disclosure, the more investors are interested in trading that company's shares, while the broader the carbon emissions' disclosure is, the smaller the bid-ask spread and the less volatile the stock price are.
\end{abstract}

Keywords: carbon emissions' disclosure, leverage, profitability, firm age, bid-ask spread, trading volume, share price volatility

JEL Classification: M410, M140, Q560 


\section{INTRODUCTION}

The purpose of this study is to examine the effect of firm characteristics on carbon emissions' disclosures, and the economic consequences of this. Therefore, in this study the question raised is whether oil, gas and coal companies in non-Annex 1 countries will gain any benefit or suffer any economic consequences if they disclose carbon emissions' information voluntarily in their annual reports.

The climate changes, such as the extreme weather that occurs at the present time, is one of the results of global warming. This global warming occurs due to the increasing levels of greenhouse gas concentrations in the earth's atmosphere. The increasing level of greenhouse gases occurs due to industrial activities (Sullivan \& Gouldson, 2013). These industrial activities require massive amounts of energy resources, which currently are derived from the earth's oil and gas fields. Choi, Lee, and Psaros (2013) explained that global warming has become both a business and a political issue that is important to most of the countries in the world, due to the assertive order from almost every political, environmental and business leader to overcome the anthropogenic challenges that trigger global warming. One of the challenges of that order is the need for an entity to understand and communicate its contribution to global warming due to its carbon emissions.

At the international level, the world responded to the threat of climate change with a United Nations (UN) convention called the United Nations Framework Convention on Climate Change (UNFCCC). One of the most important achievements in the implementation of the convention was the formulation of the Kyoto Protocol in 1997 (National Committee of Climate Change, 2013). The Kyoto Protocol is an international treaty regulating the procedures for reducing greenhouse gas emissions, so as not to disrupt the Earth's climate system (United Nation Framework on Climate Change, 2008). According to the World Wide Fund for Nature's website, in the Kyoto Protocol it is agreed that all Annex I member countries must reduce greenhouse gas emissions by an average of 5.2\% of their 1990 emissions levels, while non-Annex 1 members of the Kyoto Protocol are not required to reduce greenhouse gas emissions. Annex I member nations are developed countries, while non-Annex 1 member countries are developing countries.

The Kyoto Protocol regulates the implementation of greenhouse gas emissions' reductions for the industrial countries in Annex I by about $5 \%$ below their emission levels in 1990 , towards the 2008-2012 period through the Joint Implementation, Emission Trading and Clean Development Mechanisms. In that order, the existence of the Kyoto Protocol has emphasized the implication of carbon accounting as the obligation for the concerned companies to conduct avowal, assessment, documentation, presentation and disclosure of their carbon emissions (Irwantoko \& Basuki, 2016). According to Cotter and Najjah (2011) as well as Andrew and Cortese (2011), the disclosure of carbon emissions is a kind of environmental disclosure, and is considered to be a voluntary action.

The companies' commitment to improving their disclosure will decrease the possibility of information asymmetry occurring. This commitment is in line with the signaling theory, which explains the reason why a company has an incentive to report information voluntarily to the capital market, although this is not a mandatory report (Hapsoro, 2006). The carbon emissions' disclosure is expected to provide a good image for the company, because the company would be considered socially responsible and concerned about the environment that is affected by the 
company's operational activities. This matter is supported in the study by Eipstein and Freedman (1994) which revealed that the individual investor is attracted to the social responsibility information submitted by the company in its annual report.

The voluntary disclosure in the annual report is influenced by the particular characteristics of the company. Studies regarding the effect of company characteristics on carbon emissions' disclosures have been conducted before by Choi et al. (2013), Borghei-Ghomi and Leung (2013), Jannah and Muid (2014) as well as Pratiwi (2017). The studies conducted by Choi et al. (2013) and Borghei-Ghomi and Leung (2013) were using the variables of size, leverage, corporate governance, industry, profitability and age. Jannah and Muid (2014) used the variables of media exposure, industry type, profitability, leverage, size and environmental performance, while Pratiwi (2017) employed the variables of regulation, ownership, leverage, profitability and size. However, these studies did not provide similar results. Therefore, the authors intended to conduct advanced testing on the factors that influence the disclosure of carbon emissions by oil, gas and coal companies located in some of the non-Annex 1 countries.

Although companies in non-Annex 1 countries are not required to reduce carbon emissions, they still attempt to reduce their carbon emissions and disclose this voluntarily. It is interesting to investigate, because based on the results of previous studies; there are still inconsistencies found in the results of the factors that affect carbon emissions' disclosures.

In addition to examining the factors affecting the carbon emissions' disclosures, this study also examined the effect of the economic consequences of a carbon emissions' disclosure.

\section{LITERATURE REVIEW}

\section{Stakeholder Theory}

The stakeholder theory states that all of the stakeholders have the right to information about the organizational activities that affect them (for example pollution reports, sponsorship, security initiatives) although they do not always respond to it (Deegan, 2004). Considering the latest issues are how a company manages and evaluates its greenhouse gas emissions, the company seeks to gain legitimacy from their stakeholders for their activities through voluntary disclosures, in order to help to ensure the operational sustainability and the company's existence within the community (O'Sullivan \& O’Dwyer, 2009; Kalu et al., 2016).

\section{Carbon Emissions' Disclosure}

Carbon gas emission is the release of carbon into the atmosphere as a result of the ignition of fossil fuels, which is directly correlated with the release of carbon dioxide into the atmosphere, thus global warming is increasing rapidly (Ecolife, 2011). According to Choi et al. (2013), one of the impacts for companies, due to global warming, is the need for each entity to understand and communicate its contribution to global warming as a result of its carbon emissions. The implication of the Kyoto Protocol emphasizes carbon accounting as the obligation for the company to conduct avowal, assessment, documentation, presentation and disclosure of its carbon emissions (Irwantoko \& Basuki, 2016).

Carbon disclosure is defined as set of quantitative and qualitative information that relates to a firm's past and forecasted carbon emissions levels; its exposure to and financial implications of climate change associated risk and opportunities; and its past and future actions 
to manage these risks and opportunities of carbon emissions' disclosure (Najah, 2012). Efforts to reduce carbon emissions by companies as business actors can be identified from the carbon emissions' disclosure (Jannah and Muid, 2014). Companies that make carbon emissions' disclosure will make it easy for stakeholders to make decisions about the state of the company's carbon emissions performance, pressure companies to reduce carbon emissions, contribute to public debate on climate change policy and regulation (Ennis et al., 2012).

\section{Hypotheses Development}

\subsection{The Effect of Leverage on Carbon Emissions' Disclosures}

The information revealed by a company will attract more supervision, along with an increasing rate of company debt. The higher leverage will induce creditors to press the company harder, and to have higher expectations of the company's performance, including its environmental performance. This condition occurs because environmental performance is related to the sustainability of companies operating in the future. Therefore, a company with high leverage tends to reveal more information (Leftwich et al., 1981 and Roberts, 1992).

The studies regarding the factors that influence carbon emissions' disclosures in the developing countries show various results. Pratiwi (2017) did not find any effect of leverage on carbon emissions' disclosures, while Clarkson et al. (2008) found that leverage has an effect on environmental disclosures.

According to the past research, there are two different results related to the studies regarding the effect of leverage on carbon emissions' disclosures. Therefore, the author proposes the first hypothesis as follows:
H1: Leverage has a positive effect on carbon emissions' disclosures.

3.2. The Effect of Profitability on Carbon Emissions' Disclosures

Nurkhin (2009) states that the ability of management with responsibility in generating profit must be accompanied by the ability to carry out their social responsibilities. Through social disclosure, the company communicates to the public that the company is not only looking for profit, but also cares about the social environment.

Companies with high profitability tend to be more concerned about the environment (Pratiwi, 2017) and more able to perform social disclosure compared to companies with low profitability (Lorenzo et al., 2009). Choi et al. (2013) also found that companies with good financial conditions were able to afford the additional human or financial resources required for better voluntary reporting and disclosure of carbon emissions to withstand external pressures.

Jannah and Muid (2014) who examined the effect of profitability on carbon emissions' disclosure found that profitability had a positive effect on the carbon emissions' disclosure. While Pratiwi (2017) did not find any effect of profitability on carbon emissions' disclosure. Based on the previous research, there are two different results related to research on the effect of profitability on carbon emissions' disclosure. In accordance with the previous studies, there are two different results related to the research regarding the effect of profitability on carbon emissions' disclosures. Therefore, the author proposes the second hypothesis as follows:

H2: Profitability has a positive effect on carbon emissions' disclosures. 
3.3. The Effect of Firm Age on Carbon Emissions' Disclosures

Roberts (1992) argues that the reputation and history of involvement in social responsibility activities can become entrenched and therefore the company will always strive to carry out its social responsibility activities because it is difficult for a company to withdraw its commitment to participate in such activities. The company, which is producing carbon emissions through its normal operational activities, will obviously produce more carbon emissions the longer it continues to operate. Therefore, as part of its responsibility to the stakeholders, a longestablished company is expected to provide information regarding its carbon emissions and the efforts made to reduce them.

Several studies that test the effect of a company's age on that disclosure have been conducted. Borghei-Ghomi and Leung (2013) found that firm age has an effect on disclosures about greenhouse gases, while Chitambo and Tauringana (2014) showed that firm age has no relation with the disclosures. According to the past studies, there are different results relating to the research regarding the effect of firm age on carbon emissions' disclosures. Therefore, the author proposes a third hypothesis as follows:

H3: Firm age has a positive effect on carbon emissions' disclosures.

\subsection{The Effect of Carbon Emissions' Disclosures on the Bid-Ask Spread}

The bid-ask spread is the difference between the highest and lowest purchase prices. According to Ramadhani (2014), a high bid-ask spread occurs due to the presence of information asymmetry. According to Hapsoro (2006), one of the efforts conducted to reduce the information risk faced by the investor is to provide voluntary disclosures. The carbon emissions' disclosure is generally presented, since the manifestation of a voluntary disclosure is useful for internal and external decision making (Andrew \& Cortese, 2011). Therefore, the availability of carbon emissions' disclosures is expected to reduce information asymmetry and can be used in making decisions in order to decrease the bidask spread.

The results of previous studies on the effect of corporate social responsibility's disclosure on bid-ask spreads show different results. Ramadhani (2014) showed that corporate social responsibility has a negative effect on the bidask spread. While Fadhilla (2016) showed that corporate social responsibility has a positive effect on it. This study was conducted to reexamine the effect of carbon emissions' disclosures on the bid-ask spread. Therefore, the author proposes a fourth hypothesis as follows:

H4: Carbon emissions' disclosures have a negative effect on the bid-ask spread.

\subsection{The Effect of Carbon Emissions' Disclosures on Trading Volume}

Trading volume is an illustration of the investors' interest to sell or purchase a stock (Leuz \& Verrecchia, 2000). One of the factors that are considered when predicting a stock's price is its trading volume. Among the various elements that affect the volume of stock traded, one of the most influential elements on the fundamental valuation of a security is the availability of new information (Sun, 2003).

The research conducted by Nurdin and Cahyadinto (2006) showed that the disclosure of social and environmental themes in the annual company report has influenced investors' reactions, which consisted of a rise in the stock's price and trading volume. Leuz and Verrecchia (2000) showed that improving the disclosure activity resulted in economic consequences as embodied in the form of a decrease in the trading volume. In accordance with the past research 
regarding voluntary disclosure and trading volume, which produced different results, this research will re-test the effect of carbon emissions' disclosures on the trading volume. Therefore, the author proposes a fifth hypothesis as follows:

H5: Carbon emissions' disclosures have a positive effect on the trading volume.

\subsection{The Effect of Carbon Emissions' Disclosures on Share Price Volatility}

Share price volatility is a statistical measurement for the fluctuations of a stock's price during a certain period. In general, a company that has a low level of volatility is a more stable company. According to Cormier and Magnan (2011), the environmental and social disclosures are competing with each other to reduce information asymmetry in the stock market, while the decreasing level of information asymmetry is assessed by the decrease in a share price's volatility. With the availability of carbon emissions' disclosures, revealed by the company, the stakeholder is expected to have information transparency regarding the carbon emissions produced, and the efforts of the company to reduce those emissions. The more information that is available in a carbon emissions' disclosure is expected to be able to reduce the information asymmetry, thus it could decrease the stock's price volatility. A different conclusion was proposed by Ramadhani (2014), when his research showed there was no effect of corporate social disclosures on share price volatility.

In accordance with the past research regarding voluntary disclosures and share price volatility, which produced different results, this research will re-test the effect of carbon emissions' disclosures on the share price's volatility. Therefore, the author proposes a sixth hypothesis as follows:
H6: Carbon emissions' disclosures have a negative effect on share price volatility.

\section{Research Model}

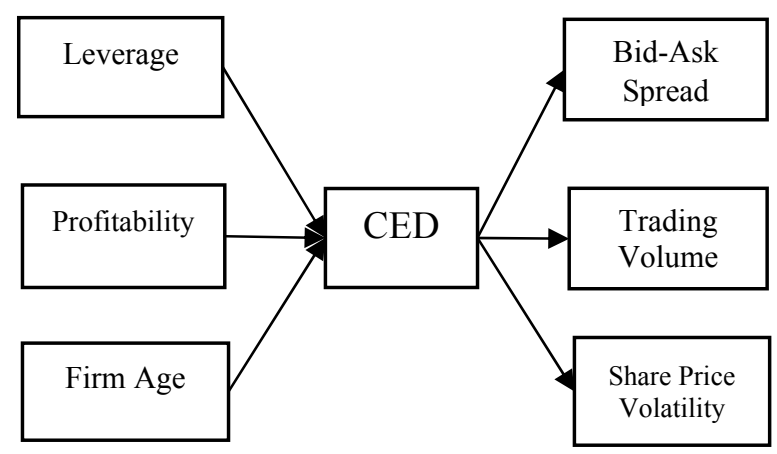

Figure 1. Theoretical model

\section{METHOD, DATA, AND ANALYSIS}

\section{Population and Sample}

The population in this research is the oil, gas and coal companies in the non-Annex 1 member countries that were available on the Osiris database in 2013-2016. The sampling technique used in this research is purposive sampling. The companies selected as samples are companies that published annual reports for the years 20132016. This approach was chosen because the year 2013 marked the beginning of the second agreement of the Kyoto Protocol to reduce carbon emissions, and 2016 reflects the current conditions.

The samples' selection criteria for this study are oil, gas and coal companies in non-Annex 1 member countries whose annual reports appeared in either the Indonesian or English language, in 2013-2016 sequentially in the Osiris database, and companies having a historical share price for the years 2013-2016 listed on the Yahoo Finance website. Based on these criteria, we obtained 68 samples that meet the criteria. After testing the outlier data, there were 6 samples that did not meet the criteria, so we obtained a final sample number of 62 
companies. The samples used consisted of companies in Indonesia, Thailand, South Africa, China and Papua New Guinea.

\section{The Measurement of Operational Variables}

\subsection{Carbon Emissions' Disclosures}

This variable is measured by giving a score of 1 (one) to companies that conducted carbon disclosures, and 0 for the companies that did not. The items used to measure carbon emissions' disclosures are adopted from the research by Choi et al. (2013).

\subsection{Leverage}

Leverage is the amount of debt a company depends on to pay for its operational activities. The leverage variable in this research is measured by calculating the total debt amount divided by the total assets owned.

\subsection{Profitability}

According to Choi et al. (2013), the profitability in this research is found by using the return on assets ratio. The return on assets is a comparison between the profit before the tax and the value of the total assets.

\subsection{Firm Age}

The firm age reveals if the company still exists and is able to compete. In this research, the measurement of firm age is calculated from the company's establishment until the observation data year (annual report) (Latifahet al., 2011).

\subsection{Bid-Ask Spread}

The bid-ask spread is the difference between the highest and lowest stock purchase value. The formula used to calculate the bid-ask spread is:

Spread $=\frac{\{(\text { bidi, } \mathrm{t}-\text { aski, } \mathrm{t}) /(\text { bidi, } \mathrm{t}+\text { aski }, \mathrm{t}) / 2\} \times 100}{n}$
Spread i,t $=$ The average difference between the highest purchase price and the lowest selling price of stock in company $i$ in one year.

Ask $=$ The lowest selling price or demand price.

Bid $=$ The highest purchase price or offer price.

$\mathrm{n}=$ The number of transaction days in one year.

\subsection{Trading Volume}

The trading volume shows the investors interest in either selling or buying a certain stock. The formula used to calculate the trading volume is:

$$
T V_{i}=\frac{\sum_{t=1}^{n} T V_{i, t}}{n}
$$

$\mathrm{TVi}=$ The average stock trading volume of company $i$ in one year.

$\mathrm{TV} i, \mathrm{t}=$ The daily stock trading volume of company $i$.

$\mathrm{n}=$ The number of transaction days in one year.

\subsection{Share Price Volatility}

Volatility is a standard deviation used to calculate the average daily price of stock traded. The formula used to calculate the share price volatility is:

$$
\sigma_{i}^{2}=\frac{\sum_{t=1}^{n}\left(X_{i, t}-\bar{X}_{i}\right)^{2}}{n-1}
$$

$\sigma_{i}^{2}=$ Variance

$\sigma_{i}=$ Standard deviation

$X_{i, t}=$ Each daily stock price for company $i$ in one year

$\bar{X}_{i}=$ The average daily stock price of company i

$\mathrm{n} \quad=$ The number of transaction days in one year. 


\section{The Data Analysis Method}

The analysis method used in this research is Structural Equation Modeling (SEM) and the analysis instrument used is Partial Least Squares (PLS) software. SEM is one of the types of multivariate analysis used in social science research.

Alternative methods that can be used to answer the research questions and to analyze the data are multiple regression analysis or two step regression (hierarchical regression). By using multiple regression analysis, the researcher must perform two steps to test each hypothesis. SEM is used in this research because in the research model there is a variable of mediation. By using SEM, the researchers need only one step to test each hypothesis.

The PLS method has many advantages over the linear regression method. One of these advantages is that PLS does not require the fulfillment of classical assumptions, such as normality, autocorrelation, multicollinearity, and heteroscedasticity, so it is suitable for testing small samples; A linear regression must meet all the classical assumptions.

The software used as an analytical tool is WarpPLS version 4.0. The software can be used to analyze complex models, non-distributed data, and data with small sample quantities (Hussein, 2015).

The consequences of using non-distributed data and a small sample on the choice of method are that the data are not normally distributed. When using non-distributed data and small samples, the test cannot use statistical tools that require the fulfillment of the classical assumptions, such as a linear regression.

\section{RESULT AND DISCUSSION}

\section{Descriptive Statistics}

The descriptive statistics of the variables used in this analysis are shown in Table 1.
Table 1

\begin{tabular}{lccccc}
\hline & $\mathrm{N}$ & Min & Max & Mean & Std. Dev \\
\hline CED & 62 & 2.0 & 17.0 & 9.5 & 4.3 \\
Lev & 62 & 0.1 & 1.0 & 0.5 & 0.2 \\
Pro & 62 & -0.5 & 0.3 & 0.0 & 0.1 \\
Age & 62 & 7.0 & 64.0 & 25.1 & 14.4 \\
BAS & 62 & 0.1 & 2.1 & 0.8 & 0.4 \\
TV & 62 & 6.4 & 19.3 & 14.2 & 3.0 \\
SPV & 62 & 0.0 & 2.2 & 0.6 & 0.5 \\
\hline
\end{tabular}

Source: Survey Data, analyzed

Table 1 shows that 62 samples were used in this study. The carbon emissions' disclosure variable has an average value of 9.5. The minimum value is 2.0 and the maximum value is 17. The leverage variable has a minimum value of 0.10 , a maximum value of 1.0 and the average value is 0.5 . The minimum value of the profitability variable is -0.5 , a maximum value is 0.3 and the average value is 0.0 . The age variable has a minimum value of 7.0 , a maximum value of 64.0 and the average value is 25.1. The bid-ask spread variable has a minimum value of 0.1 , a maximum value of 2.1 and the average value is 0.8 . The minimum value of the trading volume variable is 6.4 , the maximum value is 19.3 and the average value is 14.2. The share price volatility variable has a minimum value of 0.0 , a maximum value of 2.2 and the average value is 0.6 .

\section{The Analysis of Partial Least Square}

This analysis is used to calculate the value of the goodness of fit model, which is calculated by reviewing data from the Q-square predictive relevance, and the Average R-squared (ARS), to show the model's suitability, the Average Path Coefficient (APC) to show the correlation between variables and the Average Variance Inflation Factor (AVIF) to show the multicollinearity between the independent variables. 
The value of fit model in PLS, which was calculated by reviewing the Q-square predictive relevance, is 0.45 .

Table 2. Goodness of Fit Model

\begin{tabular}{cccc}
\hline Result & P-Value & \multicolumn{1}{c}{ Criteria } & Result \\
\hline APC $=0.276$ & $\mathrm{P}<0.001$ & Good If $\mathrm{P}<0.05$ & Accepted \\
ARS $=0.135$ & $\mathrm{P}=0.035$ & Good If $\mathrm{P}<0.05$ & Accepted \\
$\mathrm{AVIF}=1.079$ & & $P<5$ & Accepted \\
\hline
\end{tabular}

Source: Survey Data, analyzed

Table 3. Hypothesis Testing

\begin{tabular}{ccccc}
\hline & Variable & $\begin{array}{c}\text { Path } \\
\text { Coef. }\end{array}$ & P-Value & Result \\
\hline H1 & LEV -> CED & 0.30 & $<0.01$ & Accepted \\
H2 & PRO -> CED & 0.21 & $<0.01$ & Accepted \\
H3 & AGE - C CED & 0.25 & $<0.01$ & Accepted \\
H4 & CED -> BAS & -0.24 & $<0.01$ & Accepted \\
H5 & CED - > TVO & 0.29 & $<0.01$ & Accepted \\
H6 & CED -> SPV & -0.37 & $<0.01$ & Accepted \\
\hline \multicolumn{5}{l}{ Source Survey Data, analyzed }
\end{tabular}

\section{Hypotheses Discussion}

3.1. Leverage has a Positive Effect on Carbon Emissions' Disclosures

According to the result of the first hypothesis tested in this research, we found that the $P$-Value $(<0.01)$ is smaller than the determined significance level $(\leq 0.05)$ and the path coefficient value is marked as positive (0.30). This result shows that leverage has a positive effect on carbon emissions' disclosures; therefore the test result proves the first hypothesis. A higher leverage value for the company will increase the information available in its carbon emissions' disclosures. This result is from companies that try to sustain or increase their reputations, from their stakeholders' and debt-holders' perspectives, in order to maintain the possibility of obtaining loans. A similar testing result is found in Clarkson et al. (2008), who showed that companies with high leverage tend to report the information voluntarily, especially disclosures which are related to the environment.

\subsection{Profitability has a Positive Effect on Carbon Emissions' Disclosures}

According to the result of the test of the second hypothesis, we found that the $P$-Value $(<0.01)$ is smaller than the determined significance level $(\leq 0.05)$ and the path coefficient value is marked as positive $(0.21)$. This result shows that profitability has a positive effect on the carbon emissions' disclosures; therefore the test result proves the second hypothesis. Higher profitability for the company will increase the information available in the carbon emissions' disclosures. When the company earns large profits, it will face high expectations from the public. Therefore, the company will conduct disclosures to fulfill the public's expectations and increase its accountability. The result of testing the second hypothesis supports the argument of Choi et al. (2013), which explained that a company with high levels of profitability is willing to conduct carbon emissions' disclosures.

\subsection{Firm Age has a Positive Effect on Carbon Emissions' Disclosures}

According to the result of the third hypothesis tested during this research, we found that the $P$ Value $(<0.01)$ is smaller than the determined significance level $(\leq 0.05)$ and the path coefficient value was marked as positive $(0.25)$. This result shows that firm age has a positive effect on the carbon emissions' disclosures; therefore the test result proves the third hypothesis. The longer a company has been established, the more information is made available in the carbon emissions' disclosures. This condition occurs because the company has many years to complete and revise the information it makes available in its carbon emissions' disclosures. This test result supports the argument of Borghei-Ghomi and Leung 
(2013), who found that the longer a company has been established, the more information there is available in the greenhouse gases' disclosures.

\subsection{Carbon Emissions' Disclosures have a Negative Effect on the Bid-Ask Spread}

According to the test result of the fourth hypothesis, we found that the $P$-Value $(<0.01)$ is smaller than the determined significance level $(\leq 0.05)$ and the path coefficient value is marked as negative (-0.24). This result shows that carbon emissions' disclosures have a negative effect on the bid-ask spread, therefore the test result proves the fourth hypothesis. The more information that is made available in a carbon emissions' disclosure will decrease the range of the bid-ask spread. The more information that gets disclosed is expected to reduce information asymmetry, therefore the bid-ask spread will be smaller. This test result supports the argument of Ramadhani (2014) regarding the negative effect of corporate social responsibility disclosures on bid-ask spreads. The wider the information is which is disclosed under corporate social responsibility releases, then the smaller the bidask spread will be.

\subsection{Carbon Emissions' Disclosures have a Positive Effect on the Trading Volume}

According to the result of the test of the fifth hypothesis, we found that the $P$-Value $(<0.01)$ is smaller than the determined significance level $(\leq 0.05)$ and the path coefficient value was marked as positive (0.29). This result shows that carbon emissions' disclosures have a positive effect on the trading volume; therefore the test result proves the fifth hypothesis. The more details that are made available in the carbon emissions' disclosures, the investors' interest in investing in the company will increase as well. The testing result supports the argument of Ramadhani (2014) who found the disclosure of corporate social responsibility information has a positive and significant effect on the trading volume.

3.6. Carbon Emissions' Disclosures have a Negative Effect on the Share Price Volatility

According to the result of the testing of the sixth hypothesis, we found that the $P$-Value $(<0.01)$ is smaller than the determined significance level $(\leq 0.05)$ and the path coefficient value is marked as negative (-0.37). This result shows that carbon emissions' disclosures have a negative effect on share price volatility; therefore the test result proves the sixth hypothesis. The more information that is made available in the carbon emissions' disclosures will cause the share price's volatility to reduce. The more information revealed in the disclosures will reduce the information asymmetry, thus the share price's volatility will also reduce. This testing result supports the argument of Vieira and Pinho (2011) who revealed that disclosures have a negative effect on share price volatility. This condition occurs due to the decrease in information asymmetry along with the transparency improvement and the regularity of information delivery to the market.

\section{CONCLUSION}

According to the analysis conducted in this research, it can be concluded that leverage, profitability and firm age have a positive effect on the disclosure of carbon emissions. Aside from that, the carbon emissions' disclosures have a positive effect on the trading volume, and a negative effect on the bid-ask spread and the share price volatility.

The companies that have a high leverage or a high profitability level, and the longer a company has been established, all this will lead to increases in the information made available in 
the carbon emissions' disclosures. The more available that information is in the carbon emissions' disclosures will decrease the bid-ask spread and share price volatility and it will increase the trading volume.

\section{LIMITATION AND SUGGESTION}

This research recognizes limitations that could become a consideration for future research, such as the limited data of oil, gas and coal companies in the Osiris database during 2013 to 2016 . The exogenous variable in this research is the company characteristics from which we only used three proxies: Leverage, profitability and firm age.

Any future research is expected to overcome this current research's limitations by applying the following methods: First, by using another database that provides annual reports from the companies around the world.

Second, further research can add the corporate governance variable, because that variable is one of the indicators contained in the Carbon Disclosure Checklist. Choi et al. (2013) stated that it is important to know which committee (or other executive body) has overall responsibility for actions related to climate change, and the description of the mechanism by which the board (or other executive body) reviews the company's progress on climate change.

This research has implications for a number of interested parties, such as the government. The government is expected to apply tighter regulations on companies that have the potency to produce carbon emissions. This regulation can be related to the implementation of mandatory disclosures by any company that has the potential to produce carbon emissions, through carbon emissions' mandatory disclosures. For the companies, it is expected that they will have more concerns about how the environment is affected by their carbon emissions, thus they will earn legitimacy and a positive response from their stakeholders. This issue matters, because investors will be more interested in the companies that conduct carbon emissions' disclosures, which is proved by the improvement in those companies trading volumes as well as the decreasing rate of their bid-ask spreads and share price volatility.

\section{REFERENCES}

Andrew, J., \& Cortese, C. L. (2011). Carbon disclosures: Comparability, the carbon disclosure project and the greenhouse gas protocol. Australasian Accounting Business and Finance Journal, 5(4), 5-18.

Borghei-Ghomi, Z., \& Leung, P. (2013). An empirical analysis of the determinants of greenhouse gas voluntary disclosures in Australia. Accounting and Finance Research, 2(1), 110.

Chitambo, L., \& Tauringana, V. (2014). Company specific determinants of greenhouse gases' disclosures. Journal of Applied Accounting Research, 15(3), 323-338.

Choi, B. B., Lee, D., \& Psaros, J. (2013). An analysis of Australian company carbon emissions' disclosures. Pacific Accounting Review, 25(1), 58-79.

Clarkson, P. M., Li, Y., Richardson, G. D., \& Vasvari, F. P. (2008). Revisiting the relation between environmental performance and environmental disclosure: An empirical analysis. Accounting, Organizations and Society, 33(4-5), 303-327.

Cormier, D., Ledoux, M. J., \& Magnan, M. (2011). The informational contribution of social and environmental disclosures for investors. Management Decision, 49(8), 1276-1304.

Cotter, J., \&Najah, M.M. (2011). Institutional investor influence on global climate change disclosure practices. Australian Journal of Management, 37(2), 169-187. 
Deegan, C. (2004). Financial accounting theory. Sydney: McGraw-Hill Book Company.

Definition of Carbon Emission. (n.d.). Retrieved from http://www.ecolife.com/ define/carbon-emission.html.

Eipstein, M. J., \& Freedman, M. (1994). Social disclosure and the individual investor. Accounting, Auditing and Accountability Journal, 7(4), 94-108.

Ennis, C., Kottwitz, J., Lin, S. X., \& Markusson, N. (2012). Exploring the relationships between carbon disclosure and performance in FTSE 350 companies (Doctoral dissertation, working paper).

Fadhilla, A. F. (2016). Analisis hubungan corporate governance, corporate social responsibility disclosure and economic consequences: Studi empiris di pasar modal Indonesia (Unpublished master's thesis, STIE YKPN, Yogyakarta, Indonesia).

Hapsoro, D. (2006). Mekanisme corporate governance, transparansi dan konsekuensi ekonomik: Studi empiris di pasar modal Indonesia (Unpublished doctoral dissertation, Universitas Gadjah Mada, Yogyakarta, Indonesia).

Hussein, A. S. (2015). Penelitian bisnis dan manajemen menggunakan partial least squares (plls) dengan smartpls 3.0. Universitas Brawijaya.

Irwhantoko, I., \& Basuki, B. (2016). Carbon emissions' disclosure: Studi pada perusahaan manufaktur Indonesia. Jurnal Akuntansi dan Keuangan, 18(2), 92-104.

Jannah, R., \& Muid, D. (2014). Analisis faktorfaktor yang mempengaruhi carbon emissions' disclosure pada perusahaan di Indonesia (studi empiris pada perusahaan yang terdaftar di Bursa Efek Indonesia periode 2010-2012. Diponegoro Journal of Accounting, 3(2), 1000-1010.

Kalu, J. U., Buang, A., \&Aliagha, G. U. (2016). Determinants of carbon emissions' disclosure and the reduction in corporate real estate companies in Nigeria. Journal of
Environment and Earth Science, 6(2), 8794.

KP Introduction [UNFCCC Process]. (n.d.). Retrieved from http:// unfccc.int/kyoto_protocol/items/2830.php.

Latifah, S. W., Prasetyo, A., \& Rahadian, R. F. (2011). Pengaruh karakteristik perusahaan terhadap kinerja sosial berdasar ISO 26000 pada perusahaan yang termasuk dalam indeks LQ-45. Jurnal Reviu Akuntansi dan Keuangan, 1(1), 73-84.

Leftwich., R. W.,Watts, R. L.,\& Zimmerman, J. L. (1981). Voluntary corporate disclosure: The case of interim reporting. Journal of Accounting Research, 19.

Leuz, C., \& Verrecchia, R. E. (2000). The economic consequences of increased disclosure. Journal of Accounting Research, 28.

Najah, M. M. S. (2012). Carbon Risk Management, Carbon Disclosure and Stock Market Effects: An International Perspective (Doctoral dissertation, University of Southern Queensland).

National Committee of Climate Change. (2013). Mari Berdagang Karbon: The Joint Crediting Mechanism. Retrieved from http://jcm.ekon.go.id/en/uploads/files/Docu ment\%20JCM/Media/buku_carbon_isi.pdf.

Nurdin, E., \& Cahyandito, M. (2006). Pengaruh kualitas pengungkapan sosial dan lingkungan dalam laporan tahunan terhadap reaksi investor (Unpublished master's thesis, Universitas Padjajaran, Bandung).

Nurkhin, A. (2009). Corporate governance dan profitabilitas; pengaruhnya terhadap pengungkapan tanggung jawab sosial perusahaan: Studi empiris pada perusahaan yang tercatat di Bursa Efek Indonesia (Unpublished master's thesis, Universitas Diponegoro, Semarang, Indonesia).

O'Sullivan, N., \& O'Dwyer, B. (2009). Stakeholder perspectives on a financial sector legitimation process: The case of ngos and the equator principles. Accounting, Auditing \& Accountability Journal, 22(4), 553-587. 
Prado-Lorenzo, J. M., Rodríguez-Domínguez, L., Gallego-Alvarez, I., \& García-Sánchez, I. M. (2009). Factors influencing the disclosure of greenhouse gas emissions in companies world-wide. Management Decision, 47(7), 1133-1157.

Pratiwi, D. N. (2017). Pengaruh stakeholder terhadap carbon emissions' disclosure. Journal of Accounting and Finance, 2(1), 288-300.

Ramadhani, M. H. Z. K. (2014). Pengaruh pengungkapan corporate social responsibility terhadap konsekuensi ekonomi (Unpublished master's thesis, STIE YKPN, Yogyakarta, Indonesia).

Roberts, R. W. (1992). Determinants of corporate social responsibility disclosure: An application of the stakeholder theory. Accounting, Organizations and Society, 17(6), 595-612.
Sullivan, R. \& Gouldson, A. (2013). Ten years of corporate action on climate change: What do we have to show for it? Energy Policy, 60, 733-740.

Sun, W. (2003). Relationship between trading volume and security prices and returns. Area Exam Report, Technical Report, MIT Laboratory for Information and Decision Systems.

United Nation Framework on Climate Change. (2008). Kyoto Protocol Reference Manual on Accounting of Emissions and Assigned Amount. Retrivied from www.unfecc.int.

Vieira, E.,\& C. Pinho. (2011). Financial disclosure and stock price volatility: Evidence from portugal and belgium. Portuguese Journal of Accounting and Management, 11, 77-108.

Notice: The Journal of Indonesian Economy and Business and its Board of Editors are not responsible for any errors or flaws found in this article. The authors take full responsibility for their work. 